NBER WORKING PAPER SERIES

\title{
DO "REVERSE PAYMENT" SETTLEMENTS OF BRAND-GENERIC PATENT DISPUTES IN THE PHARMACEUTICAL INDUSTRY CONSTITUTE AN ANTICOMPETITIVE PAY FOR DELAY?
}

\author{
Keith M. Drake \\ Martha A. Starr \\ Thomas McGuire \\ Working Paper 20292 \\ http://www.nber.org/papers/w20292
NATIONAL BUREAU OF ECONOMIC RESEARCH
1050 Massachusetts Avenue
Cambridge, MA 02138
July 2014

We are grateful to Bennett Erickson and Addison Wood for expert help with data preparation and analysis, and to Laura Panattoni and session participants at the June, 2014 American Society of Heath Economics meetings for valuable comments on an earlier version of the paper. We also thank Moneil Abu Speitan, Mike Augusteijn, Sebastian Bauhoff, Rena Conti, Abe Dunn, Robert Drake, Randy Ellis, Robert Feinberg, Ray Hartman, Laura Hatfield, C. Scott Hemphill, Haiden Huskamp, Anupam Jena, Tim Layton, R. Forrest McCluer, Eileen Morrison, Joseph Newhouse, Ketan Patel, Renee Rushnawitz, Julie Shi and James Sigel for insightful comments and suggestions. Responsibility for the analyses and conclusions expressed here is the authors' own. The views expressed herein are those of the authors and do not necessarily reflect the views of the National Bureau of Economic Research.

At least one co-author has disclosed a financial relationship of potential relevance for this research. Further information is available online at http://www.nber.org/papers/w20292.ack

NBER working papers are circulated for discussion and comment purposes. They have not been peerreviewed or been subject to the review by the NBER Board of Directors that accompanies official NBER publications.

(C) 2014 by Keith M. Drake, Martha A. Starr, and Thomas McGuire. All rights reserved. Short sections of text, not to exceed two paragraphs, may be quoted without explicit permission provided that full credit, including $\odot$ notice, is given to the source. 
Do "Reverse Payment" Settlements of Brand-Generic Patent Disputes in the Pharmaceutical Industry Constitute an Anticompetitive Pay for Delay?

Keith M. Drake, Martha A. Starr, and Thomas McGuire

NBER Working Paper No. 20292

July 2014

JEL No. I11,L41,L65

\begin{abstract}
$\underline{\text { ABSTRACT }}$
Brand and generic drug manufacturers frequently settle patent litigation on terms that include a payment to the generic manufacturer along with a specified date at which the generic would enter the market. The Federal Trade Commission contends that these agreements extend the brand's market exclusivity and amount to anticompetitive divisions of the market. The parties involved defend the settlements as normal business agreements that reduce business risk associated with litigation. The anticompetitive hypothesis implies brand stock prices should rise with announcement of the settlement. We classify 68 brand-generic settlements from 1993 to the present into those with and without an indication of a "reverse payment" from the brand to the generic, and conduct an event study of the announcement of the patent settlements on the stock price of the brand. For settlements with an indication of a reverse payment, brand stock prices rise on average $6 \%$ at the announcement. A "control group" of brand-generic settlements without indication of a reverse payment had no significant effect on the brands' stock prices. Our results support the hypothesis that settlements with a reverse payment increase the expected profits of the brand manufacturer and are anticompetitive.
\end{abstract}

Keith M. Drake

Greylock McKinnon Associates

One Memorial Drive

14th Floor

Cambridge, MA 02142

Keith.M.Drake@Dartmouth.edu

Martha A. Starr

Department of Economics

American University

4400 Massachusetts Ave. NW

Washington, DC 20016

mstarr@american.edu
Thomas McGuire

Department of Health Care Policy

Harvard Medical School

180 Longwood Avenue

Boston, MA 02115

and NBER

mcguire@hcp.med.harvard.edu 


\section{Introduction}

Consumers pay high prices for innovative drugs protected by a patent monopoly, but prices fall rapidly once generic equivalents enter and compete. Consumers thus have both a short-term interest in rapid entry of generic competitors and a long-term interest in promoting the drug discovery spurred by the promise of patent protection. Congress rebalanced regulation of this trade-off with the Drug Price Competition and Patent Term Restoration Act of 1984 (Public Law 98-417), commonly called the "Hatch-Waxman Act" (H-W), which extended the effective patent life for drugs and simultaneously eased entry requirements for generic alternatives. The Act also created financial incentives for generic companies to challenge weak or invalid patents. As $\mathrm{H}-\mathrm{W}$ anticipated, these generic challenges have led to patent infringement suits filed by brand manufacturers. H-W did not, however, anticipate that brand and generic manufacturers would use closed-door settlement negotiations to divide the market for the drug, increasing their joint profits at the expense of consumers -- the allegation of the Federal Trade Commission (FTC) and some scholars (FTC 2010; Hovenkamp, Janis and Lemley 2003; Cotter 2003; Leffler and Leffler 2003; Elhauge and Krueger 2012; Edlin et al. 2013). Many of these patent-suit settlements have the unusual and troubling feature that the plaintiff (the brand company, the party alleging harm) pays the defendant (the generic company, the party allegedly doing the harm) in exchange for an agreed-upon generic entry date; hence, the label of "reverse payment" or the more pejorative, “pay-for-delay,” for these patent settlements.

While the FTC, private parties, and some scholars contend these settlements amount to agreements in restraint of trade, the parties involved and other scholars defend them as normal compromises to settle patent litigation (Green 1995; Willig and Bigelow 2004; Yu and Chatterji 2011; Harris et al. 2014). Over more than ten years, legal challenges to the settlements received 
inconsistent treatment by Courts of Appeals. ${ }^{1}$ In 2013, the Supreme Court addressed the issue in FTC v. Actavis, Inc. (133 U.S. 2223 [2013]). The Court held that brand-generic settlements should be subject to a rule-of-reason test: the presence of a "large, unexplained" payment from the brand to the generic deserves legal scrutiny but is not by itself conclusive regarding anticompetitive delays in generic entry. ${ }^{2}$ The Court reasoned that there might be normal business purposes served by the brand-to-generic payment; for example, the payment-with-entrydate agreement might be a compromise reducing uncertainty in payoffs for both parties (133 U.S. 2223, 2226).

A great deal is at stake in determining whether these brand-generic settlement agreements are anticompetitive. Since 2003, drug manufacturers have been required to file settlement agreements with the FTC, and the FTC used these filings to estimate that reverse-payment settlements raised drug costs to consumers by $\$ 3.5$ billion in one year alone (FTC 2010, 2). In federal fiscal year 2012, the FTC (2013) reported a record number (40) of brand-generic settlements including some form of a potential reverse payment.

This paper uses data on the movements of the brand manufacturer's stock price as the settlement is announced to test the competing hypotheses about the nature of the agreements. Shapiro (2003a), Edlin et al. (2013) and Elhauge and Krueger (2012) argue that if the settlement extends the brand's monopoly period beyond the time expected with litigation, the agreement

\footnotetext{
${ }^{1}$ Elhauge and Kreuger (2012) contains a review. The Sixth Circuit was at one end of the range, concluding that all settlements including a reverse payment were per se illegal (In re Cardizem CD Antitrust Litigation, 332 F. 3d 896 [2003]). The Eleventh Circuit determined that reverse payment cases depended on whether the settlement extended the patent beyond the expected outcome of litigation and thus should be decided on a rule of reason basis (ScheringPlough v. FTC, 402 F.3d 1056 [2005] and Valley Drug Co. v. Geneva Pharm., Inc., 344 F.3d 1294 [2003]). At the other end of the range, the Second Circuit held that a settlement including a reverse payment was only illegal if the patent was a sham or delayed generic entry beyond the patent's expiry (In re Tamoxifen Citrate Antitrust Litigation, 466 F.3d 187 [2006]). Some other courts then adopted this last position (for example, see FTC v. Watson Pharm., Inc., 677 F.3d 1298 [2012]), prior to the Supreme Court ruling.

${ }^{2}$ For discussion, see Edlin et al. (2013).
} 
harms consumers and is anticompetitive. The term "time expected with litigation" refers to the period of monopoly sales ending at the expected value of the date of generic entry had the patent litigation been pursued to conclusion, recognizing that the outcome of that litigation is uncertain. We discuss this term in more detail below, but here note that if the agreed-upon entry date falls after this expected value, the brand's expected profit should increase. This "more monopoly" feature of reverse-payment settlements harms consumers and leads to the empirical implication of the "anticompetitive" hypothesis that the stock price of the brand manufacturer should go up with announcement of the settlement. Conversely, company press releases claim that the parties settled in order to eliminate uncertainty associated with litigation. Willig and Bigelow (2004) and Yu and Chatterji (2011) argue that the payment to a generic manufacturer could be a "risk premium” agreed upon by risk-averse managers at the brand. ${ }^{3}$ Taken in isolation, the empirical implication of the "risk-mitigation" hypothesis is that by paying a risk premium and sacrificing expected profits, the manufacturer's stock price should be adversely affected by the announcement of the settlement. ${ }^{4}$ Settling litigation can be motivated by reasons other than extending monopoly or avoiding managerial risk. Settlement avoids future litigation costs and diversion of other internal company resources. These cost savings with settlement might cause the stock price to rise with settlement. Considering these reasons for settlement in aggregate, the principle implication of the hypothesis that reverse-payment settlements are anticompetitive is

\footnotetext{
${ }^{3}$ The dispute about interpretation of reverse-payment settlements continued beyond Actavis. See the exchange between Edlin et al. (2013) and Harris et al. (2014).

${ }^{4}$ In the writings around this issue, the word "risk" is used in two different ways, to mean either "chance of" or "uncertainty." For an example of the first meaning, in Actavis (133 U.S. 2223, 2236), the Supreme Court, is concerned with anticompetitive effects when "a patentee is using its monopoly profits to avoid the risk of patent invalidation or a finding of non-infringement." In the economics-related writings, "risk aversion" and "risk mitigation" use the word in the sense of "uncertainty." In this paper, we use the term "risk" as meaning "uncertainty."
} 
that settlements with a reverse payment should increase brand stock prices more than a settlement agreed upon for the "normal” reasons.

To test for this effect, we identified 27 settlements since 1993 that contained indication of both a reverse payment and an agreed-upon generic entry date. ${ }^{5}$ Consistent with the anticompetitive hypothesis, stock prices of brand manufacturers increased by an average of $6 \%$ when these settlements were announced. We also tested for a stock price jump upon announcement of brand-generic patent settlements in 41 settlements with no indication of a reverse payment, ${ }^{6}$ and found that these settlements had no significant effect on stock prices. Comparing the two, the positive effect on stock prices for settlements with indication of reverse payment is significantly greater than for our "control group” of those without such an indication. We interpret these findings as supporting the hypothesis that settlements with a reverse payment extend the expected time of brand exclusivity and therefore harm consumers.

Our paper complements earlier work by Panattoni (2011) and Jacobo-Rubio, Turner, and Williams (2013) concerning the effect of court decisions in brand-generic patent disputes. Both of these papers applied event-study methods to a set of cases in which the parties followed through with litigation. Panattoni found that when the parties wait for a District Court decision, brands win the patent litigation about 50 percent of the time. A brand victory boosted its stock prices, and the effect was similar to the $6 \%$ increase reported in this study. Although our methods and results are similar to those in Panattoni and Jacobo-Rubio, Turner, and Williams,

\footnotetext{
${ }^{5}$ As described in section 4.1, the 27 settlements lead to 31 stock-price observations because four settlements with indication of a reverse payment involved a drug with a profit- or revenue-sharing agreement between two brand companies.

${ }^{6}$ Our analysis includes 44 stock-price observations because three settlements without indication of a reverse payment involved a drug with a profit- or revenue-sharing agreement between two brand companies.
} 
our work tests the effect of a different legal event. At the close of this paper, we discuss this distinction and compare our results to theirs in more detail.

The next section of the paper presents background information on H-W and brandgeneric patent settlements. Section 3 develops the empirical implications of the anticompetitive and risk-mitigation hypotheses for the movement of stock prices around settlement. Section 4 presents the data used for the empirical analysis and explains the event-study methodology. Section 5 contains the main results, including a variety of alternative specifications to check the robustness of our findings. Section 6 discusses the findings and concludes.

\section{Regulation of Generic Entry and Patent Dispute Settlement Practices}

$\mathrm{H}-\mathrm{W}$ defines the terms under which generic versions of previously approved drugs may be approved for marketing. A generic manufacturer submits an abbreviated new drug application (ANDA) required to demonstrate generic bio-equivalence to the branded drug. ${ }^{7} \mathrm{H}-\mathrm{W}$ also creates incentives for generic manufacturers to challenge weak or invalid patents in order to prevent such patents from blocking competition from lower-priced generics. A generic manufacturer challenging patents and attempting to compete with a branded drug prior to expiration of a patent on the brand may be awarded a period of 180 days following their entry during which the FDA may approve no other generic product. To qualify for the 180-day exclusivity period, the generic manufacturer must be the first-to-file an ANDA under a so-called “Paragraph IV certification” ( $\mathbb{I V}$ ) in which the generic claims that patents covering the drug subject to the ANDA are invalid and/or unenforceable. The 180-day period of protected competition is highly lucrative to generic manufacturers (GPhA 2006).

\footnotetext{
${ }^{7}$ Bio-equivalence means that the active ingredient in the generic is the same as in the branded version and that it is released and absorbed into the body at the same rate in the branded and generic versions.
} 
Under a ๆ IV submission, the generic manufacturer must notify the brand manufacturer when it files an ANDA. The brand manufacturer then has 45 days to file litigation claiming patent infringement. If the brand manufacturer files an infringement suit within 45 days, FDA approval of the generic ANDA is withheld until the earliest of the following events: (1) the date the patent expires; (2) a final court determination of non-infringement or patent invalidity in the resulting litigation; or (3) the expiration of 30 months from the date of the receipt by the incumbent of the notice of 9 IV certification. Because (3) is often the earliest event to occur, the automatic delay in FDA approval of the generic is often called the "30-month stay.” JacoboRubio, Turner, and Williams $(2013,2)$ identify 304 drugs for which the brand sued a generic in connection with a I IV patent challenge. Fifty-three percent of these were decided in federal District Court, and the others were settled, dismissed, or dropped.

Since the passage of $\mathrm{H}-\mathrm{W}$, generic products have expanded rapidly in pharmaceutical markets. In 1984, generic drugs accounted for less than $20 \%$ of prescriptions sold in the U.S. (Berndt and Aitken 2011). A study by the Congressional Budget Office (CBO) showed that HW made it "easier and less costly” for generic drugs to enter the market (CBO 1998, xiii). By 2013, over 80\% of prescriptions were filled with generic drugs (IMS Health 2013). FTC testimony to the U.S. Senate called special attention to the role of $q$ IV challenges in helping save consumers money: “Generic competition following successful patent challenges involving just four major brand-name drugs is estimated to have saved consumers more than $\$ 9$ billion” (FTC 2007, 3-4).

A ๆ IV patent challenge and the subsequent brand-initiated infringement suit often can end with a settlement that sets the terms for generic entry along with a "reverse payment" from 
the brand to the generic manufacturer. ${ }^{8}$ The form of payment has evolved over time, possibly in response to legal scrutiny. In the 1990s, brand manufacturers simply paid cash to settle 9 IV disputes. ${ }^{9}$ After legal challenges from antitrust authorities, cash payments became less frequent, and settlements increasingly involved business agreements between the brand and generic. ${ }^{10}$ These business agreements may have no apparent connection to the settlement of the patent dispute, but are typically signed on the same day as the patent settlement. For example, the brand might license the generic to distribute a different drug product altogether, allowing for some profits to the generic. Hemphill $(2009,633)$ found that these peripheral agreements between brands and generics were rare outside of ๆ IV settlements, and that "the overall pattern suggests a disguised means to confer payment.” Brand-generic settlement agreements also may include a clause whereby the brand agrees to not launch an "authorized generic" version of the drug during the 180-day exclusivity period enjoyed by the generic, effecting a payment from brand to generic by approximately doubling the generic's sales and profits during the lucrative 180-day exclusivity period (FTC 2011). ${ }^{11}$ When we classify settlements below, we will regard cash payments, contemporaneous business arrangements, and no-authorized generic clauses as potential "payments" from the brand to the generic.

In unconstrained negotiations, firms will be led to terms that maximize their joint profits (Shapiro 2003a, 394). In the case of brand-generic patent settlements, joint profits are

\footnotetext{
${ }^{8}$ Of 294 ๆ IV litigation cases ending between 1984 and 2012, Jacobo-Rubio, Turner, and Williams $(2013,15)$ found that the brand won $28.6 \%$, the generic won $25.5 \%$, and $45.9 \%$ were settled or dismissed. Similarly, Greene and Steadman $(2010,4)$ found that $47 \%$ of the Paragraph IV litigation cases ending between 2000 and 2009 were settled.

${ }^{9}$ For example, in 1995, GlaxoSmithKline paid GenPharm approximately $\$ 133$ million in a settlement involving an agreed-upon generic entry date for the blockbuster drug Zantac (Hemphill 2009, 657).

${ }^{10}$ Hemphill (2009) describes the evolution of pay-for-delay settlements from 1993 to 2009 using a list he constructed from publicly available information.

${ }^{11}$ For example, in 2006, Bristol-Myers Squibb agreed with generic manufacturer Apotex not to launch an authorized generic of Plavix in exchange for an agreed-upon generic entry date (Hemphill 2009).
} 
maximized if the generic stays out and the brand maintains the high monopoly price as long as possible. As the Supreme Court recognized in Actavis (133 U.S. 2223), a settlement in which the generic company takes a payment in exchange for an agreed-upon entry date thus has the potential to harm consumers. Determining whether such a settlement actually does harm consumers requires determination of whether the agreed-upon entry date constitutes a "delay" in generic entry. The meaning of "delay" in brand-generic settlements has been clarified by researchers and we rely on their analysis in the next section to derive our alternative empirical hypotheses. Delayed entry by the 9 IV first-filer has special power because the 180-day exclusivity rule keeps out not just the generic manufacturer in litigation but can block other potential entrants as well. The FTC (2010) takes the position that settlements involving payment from the brand to the generic generally do delay entry and harm consumers.

An entirely different narrative characterizes these brand-generic agreements as normal settlement agreements reflecting compromises to avoid the cost of litigation and reduce business risk associated with uncertain outcomes of the legal process. ${ }^{12}$ Willig and Bigelow (2004), Yu and Chatterji (2011) and Harris et al. (2014) argue that the brand's incentive to reduce risk and avoid litigation costs could account for "reverse payments" without implying an anticompetitive delay in generic entry. ${ }^{13}$ Press releases announcing settlements often refer to risk reduction. For example, in one release, the chief executive of the brand company contended that the "settlement

\footnotetext{
${ }^{12}$ For example, following the Supreme Court's ruling in Actavis in June 2013 (133 U.S. 2223), the trade association Pharmaceutical Research and Manufacturers of America (2013) argued that "fully litigating patent disputes can result in substantial costs for both innovator and generic companies, create business uncertainty, and can result in delayed availability of generic drugs. Patent settlements allow generics to come on the market before innovator pharmaceutical company patents expire, thereby increasing patient access to lower cost generic drugs.”

${ }^{13}$ Authors also contend that divergent expectations about success in litigation, which here come down to the issue of the strength or weakness of the patent at issue, might call for a payment to the generic to induce settlement. If the generic is overly optimistic about its chances of success in litigation it might "hold out" and require a payment from the brand to settle. See Willig and Bigelow (2004). Elhauge and Krueger (2012), however, point out that for the brand to be willing to make a payment (in excess of future litigation costs) to settle still implies that from the brand's point of view, a "delay" is being achieved and the agreement is anticompetitive.
} 
is a business decision that eliminates the risk of the [generic] challenge, having regard to the uncertainties of any jury trial involving highly technical information and complex issues of patent law” (Green 1995).

\section{Implications of Anticompetitive Conduct and Risk Mitigation for Brand Company}

\section{Stock Prices}

The alternative views of brand-generic settlement agreements entailing a reversepayment imply opposite movements of the brand's stock after announcement of such a settlement. We make the standard assumption in financial economics that stock prices impound all currently available information about the company's expected profits, so that favorable or unfavorable "news" to investors will rapidly move stock prices. ${ }^{14}$ Our tests rely on the assumption that the announcement of the settlement constitutes "news" and we select our sample with this requirement in mind.

\subsection{The Agreement Delays Generic Entry and is Anticompetitive: Brand Stock Prices Go Up}

Shapiro (2003b, 70) articulated a standard for whether a patent settlement is anticompetitive: “... Antitrust gives consumers the right to the level of competition that would have prevailed, on average, had the two parties litigated the patent dispute to resolution in the courts." This rule can be applied to ๆ IV cases, as Shapiro did, to clarify the concept of "delay" (Shapiro 2003a, 407-8). If the brand wins in litigation, it will sell as a monopolist until the date of patent expiration. If the generic wins in litigation, the brand and generic will compete directly after the close of litigation. ${ }^{15}$ The average consumer experience is a weighted average of these

\footnotetext{
${ }^{14}$ See MacKinlay (1997) and Campbell, Lo and MacKinlay (1997). Panattoni (2011) provides discussion in the context of 9 IV disputes.

${ }^{15}$ The brand and generic would compete as a duopoly until the completion of the 180-day exclusivity period, after which other generics with FDA approval could potentially enter.
} 
two market outcomes, with the weights determined by the probability the patent would be found valid and infringed. A “delay" then exists if the agreed-upon date is past the average date of generic entry associated with the competitive outcome, i.e., following through with litigation. Elhauge and Krueger $(2012,293)$ apply the same standard: “...Any settlement exclusion period that exceeds the expected litigation period necessarily harms ex post consumer welfare.”

The "expected date of generic entry" depends on the likelihood the brand wins the patent litigation, and is not directly observed. This is why "reverse payments" from the brand to the generic are a red flag in I IV patent settlements. If the brand makes a "large, unexplained” reverse payment to the generic in connection with a settlement, the brand must be getting something in exchange. ${ }^{16}$ Stated simply, the anticompetitive hypothesis is that the brand is buying more time to sell as a monopoly from the generic willing (thanks to the payment) to settle for a date later than it expects with litigation.

This logic ties to profits and stock values and provides the basis for our tests. The litigation (competitive) route yields an expected profit to the brand, recognizing that the patent may or may not be found by the court to be valid and infringed. This expected profit is associated with the competitive outcome and with a particular market valuation of the brand's stock. If, in settlement, the brand manufacturer in effect buys a longer period of monopoly sales by "paying for delay" with a "reverse payment," expected profits to the brand go up. Investors capitalize the value of the future higher profit flow into stock prices. The brand shares some of these higher profits with the generic, in the form of a reverse payment, to induce it to accede to delay.

16 "Large" is generally defined in relation to avoided future litigation costs. Shapiro (2003a) and Elhauge and Krueger (2012) both propose comparing the brand-to-generic payment with the brand's expected litigation cost as a basis for inferring that the brand is buying extra time for monopoly sales. The Supreme Court, in Actavis (133 U.S. 2223, 2226), also emphasized the role of large unexplained payments in drawing inferences about the anticompetitive nature of brand-generic settlements. 


\subsection{The Agreement Mitigates Risk to Brand Management at the Expense of Expected Profits:}

\section{Brand Stock Prices are Adversely Affected}

A for-profit company is normally assumed to maximize profits (or expected profits) in the interest of its shareholders. Shareholders want managers to maximize expected profits because shareholders can diversify risks as needed by portfolio choices. ${ }^{17}$ The risk-mitigation hypothesis supposes managers' interests diverge from those of shareholders; specifically, that managers have a utility function negatively affected by uncertainty or risk. A risk-averse decision maker prefers a lower certain profit over a situation with a higher expected profit but with some uncertainty. The difference between the expected profit in the risky situation and the lowest certain profit a decision maker would accept as an alternative is referred to as the "risk premium,” a measure of the degree of aversion to risk in the decision maker's utility.

In the context of 9 IV suits, risk-averse management at a brand would prefer a settlement with a more certain flow of profits to the uncertain outcome associated with patent litigation in which there might be small profits or large profits depending on the court verdict. Management might be willing to pay for this reduction in uncertainty in the form of a "reverse payment" to a generic to achieve a settlement. The risk mitigation hypothesis is that the payment buys subjective relief for risk-averse managers and is not a quid pro quo for delay of generic entry beyond the expected outcome from litigation. Interpreting the "reverse payment" as a risk premium is an alternative explanation to the argument that the brand is buying extra time to sell as a monopolist. The payment to the generic is not then a sharing of elevated joint profits, but a sacrifice in expected profits agreed to by risk-averse managers. If brand management acts in

\footnotetext{
17 Shareholders may be risk averse but can diversify their investments to eliminate risk that is referred to as "nonsystematic.” Firm-specific risk is non-systematic.
} 
their own interest (utility) at the expense of shareholders' interests (expected profits),

announcement of the settlement should adversely influence stock prices.

Authors favoring the risk mitigation hypothesis emphasize the separation of ownership and control in the modern large corporation, a venerable position in the economics of firm behavior. ${ }^{18}$ Other authors, writing in the context of brand-generic settlements, argue that the risk-aversion idea should be rejected in principle, based on general theory of the firm and the size of the corporate actors involved in drug patent litigation. For example, Bulow $(2004,162)$ argues: ${ }^{19}$

“...Basic capital market theory would say that if the litigation risk is non-systematic and the firms' managers act as fiduciaries for well-diversified stockholders then firms should be risk-neutral over the litigation. As an empirical matter, risk aversion should not be terribly relevant in most cases. The market values of large pharmas are enormous relative to the amount at stake in most of these cases, even if the absolute dollars may be in the hundreds of millions."

A decrease in the brand firm's stock price would be detectable only if the risk premium was large relative to the firm's expected earnings. Some "reverse payments" have been in the hundreds of millions of dollars and may have a measureable empirical effect. Additionally, a risk premium would depress a brand firm's stock price to the extent that investors did not believe the payment was gaining anything for the company other than increasing managers' expected utility.

\footnotetext{
${ }^{18}$ See Willig and Bigelow (2004, 666), Dickey et al (2010, 381), and Cotter (2004, 1073). Separation of ownership and control in a firm is the classic agency problem depicted by Fama and Jensen (1983), following Berle and Means (1932) and Jensen and Meckling (1976), wherein managers of large corporations act as imperfect agents of shareholders because the former "do not bear a substantial share of the wealth effects of their decisions" (Fama and Jensen 1983, 301).

${ }^{19}$ See Elhauge and Krueger $(2012,312)$ for a similar argument.
} 


\subsection{Other Rationales for Settlement}

“Normal business agreements" that happen to be signed on the same day as the settlement of the patent dispute might also influence a brand's stock values. If these voluntary agreements serve the interests of both parties, they could be expected to have a non-negative impact on brand share prices.

\subsection{Summary}

Our principal interest is in testing whether settlements with an indication of a reverse payment and an agreed-upon generic entry date harm consumers and are anticompetitive. This hypothesis is supported if the stock price of a brand goes up at the announcement of a settlement with a reverse payment. A refinement of the test recognizes that settlements might occur for other reasons with an ambiguous combined effect on stock prices. The refinement tests whether settlements with an indication of a reverse payment have a greater positive impact on share price than do agreements without such an indication.

\section{Data and Event Study Methods}

\subsection{Identification of Settlements and Reverse Payment Indications}

To identify IIV settlements for which changes in share prices can be used to quantify expected effects on profits, we systematically searched electronic databases for news of settlements between brand and first-to-file generic manufacturers occurring between 1993 and $2013 .^{20}$ Following Panattoni (2011), we started with the FDA's list of “q IV Patent

\footnotetext{
${ }^{20}$ Although we considered all settlements occurring after the passage of H-W in 1984 eligible for inclusion, Nolvadex (1993) was the earliest we identified. Hemphill (2009), who also relied on publicly available information, also listed Nolvadex as the earliest reverse payment settlement.
} 
Certifications,” which included 906 ANDAs when we downloaded it in January $2014{ }^{21}$ To identify IIV settlements that were announced in media outlets, press releases, and other widely accessible information sources, we used the LexisNexis and Factiva databases, as well as Google internet searches, to search on the drug name and variations of the phrases "settle," "patent dispute,” “patent challenge,” and "patent litigation.” We found 110 settlements covered in these sources where it could be established that the generic company was either first-to-file or first-tosettle if multiple generic companies had filed concurrently. In most cases, the announcement took the form of a press release distributed via a wire service like Associated Press, Bloomberg, or PR Newswire. Example excerpts are shown in Table $1 .^{22}$

From among the 110 cases with settlement information, we identified a subset of 68 meeting requirements for the event-study approach, namely that: (a) there was a clear announcement date of the settlement; (b) the brand company was publicly held and traded on the New York Stock Exchange or the NASDAQ Stock Exchange; and (c) no other news was released at the time of the announcement that may have affected the company's share price. ${ }^{23}$ In most cases, the announcement date was clear and consistently reported across news sources. ${ }^{24}$ For settlements referred to in multiple press releases with different dates, we used the date of the earliest release. To ensure that the criteria for selecting cases were systematically and objectively applied, two of us independently reviewed the announcement information, and

\footnotetext{
${ }^{21}$ Food and Drug Administration. "Paragraph IV Patent Certifications.” http://www.fda.gov/drugs/developmentapprovalprocess/howdrugsaredevelopedandapproved/approvalapplications/a bbreviatednewdrugapplicationandagenerics/ucm047676.htm.

${ }^{22}$ An appendix recording news sources for each announcement along with an abstract of the information in the announcement is available from the authors upon request.

${ }^{23}$ We excluded three settlements where the announcement coincided with the brand firm's quarterly earnings report, one that coincided with the release of a damaging study about negative side effects of the drug, and one for which commercial sales rights were sold to a different company on the same day of the settlement.

${ }^{24}$ In some instances, the first announcement was made after the end of the trading day. Where this was clearly the case, we took the announcement date to be the following day.
} 
discussed cases where the date and/or terms of settlements were potentially unclear. If we could not clearly establish when news of a settlement was first released, the case was not included in the sample.

From these 68 settlements, 27 announcements contained indication of a reverse payment and an agreed-upon entry date. Specifically, announcements for these 27 settlements reported: (a) an agreed-upon entry date for the generic drug sometime after the date of the settlement, and (b) an explicit payment to the generic company or other contemporaneous business agreement that could potentially be used to transfer value to the generic. As noted earlier, a reverse payment could take the form of a cash payment to the generic, a pledge by the brand not to launch an authorized generic in the 180-day exclusivity period, co-marketing arrangements, or other business agreements. Again, to ensure that criteria for categorizing the settlements were objectively and consistently applied, two of us reviewed information on settlement terms included in announcements, and discussed and reconciled the few cases with unclear prima facie information. The announcement excerpts in Table 1 contain text that we bolded to illustrate what we regarded to be indication of a reverse payment. We required a clear indication of reverse payment for a settlement to be so classified; otherwise cases were classified as without indication of a reverse payment. ${ }^{25}$ Table 2 lists the 27 settlements we categorize as containing indication of a reverse payment. Several settlements covered multiple drugs, but because our interest is in the effect of the announcement on the brand company's share price, we take these announcements to constitute a single “event.” In four settlements, the brand drug was marketed under some form of profit- or revenue-sharing arrangement between two companies, so we take

\footnotetext{
${ }^{25}$ The appendix available upon request includes an abstract describing the settlement from one or more news sources for all the settlements contained in Tables 2 and 3. In that appendix, we bold key phrases that we relied upon to infer the potential for a reverse payment.
} 
the announcement of the settlement to have caused two "events." As a result, the 27 settlements yield 31 events.

Announcements for the other 41 settlements in the group of 68 satisfying criteria for an event study contained no indication of a reverse payment or provided insufficient information on terms of the settlement to determine whether a reverse payment was part of the settlement. Many of these announcements referred to an agreed-upon generic entry date, but stated that all other terms of the settlement were confidential. Others conveyed some information on the settlement's terms but did not report an agreed-upon entry date. The common element in the group is that, from an event-study perspective, the announcement did not convey information to investors indicating a reverse payment, but did clearly relate that a settlement had been made. As such, share-price changes in this group provide a benchmark against which share-price changes associated with settlements with indication of reverse payments can be compared. Table 3 lists the 41 settlements without indication of a reverse payment. Three of the settlements covered drugs that were marketed under profit-sharing arrangements between two brand manufacturers, so the 41 settlements yield 44 events.

To corroborate that our methods performed well in identifying I IV settlements with public announcements, we compared our data to lists compiled by Hemphill (2009) and U.S. PIRG (2013), and found substantial overlap, but no additional settlements. The FTC (2013), which reviews the terms of all II IV suits, reported 117 potential pay-for-delay settlements involving first-to-file generics between 2004 and 2012. This figure is larger than ours because we apply several criteria to be able to conduct the event study. ${ }^{26}$

\footnotetext{
${ }^{26}$ The FTC compilation includes settlements with multiple first-to-file generic manufacturers for some drugs. It also includes settlements with companies that are not publicly traded; settlements with companies traded only on foreign markets; settlements that were not publicly reported or not covered in the outlets we used to identify news available to investors; settlements for which the announcement date was not clear; and settlements that coincided with another
} 
We also examined the validity of our reverse-payment indication classifications by comparing our lists to a recent compilation of litigation cases that had reverse payments at issue (Hemphill 2014). Of the 18 cases with reverse payments at issue, we classified ten as including indication of a reverse payment. We excluded seven because they did not meet our criteria for inclusion in an event study. We classified one case (Effexor XR) as not including indication of reverse payment because press releases at the time of the settlement did not describe terms consistent with a reverse payment.

\subsection{Data on Share Prices and Drug Sales}

Daily data on stock prices and trading volume of the brand firms are from the Center for Research in Security Prices (CRSP) financial database. ${ }^{27}$ Because we expect that news of a settlement will have a larger effect on the share price of a company for which the drug in question is expected to figure materially in its expected future revenues, we follow Panattoni (2011) and measure the drug's importance as the ratio of sales of the brand drug to the company's total sales or operating revenues for the most recent year. Data on the brand manufacturers’ total annual sales were downloaded from the Compustat Industrial Files, ${ }^{28}$ and specific drug sales in the U.S. were taken from www.drugs.com's annual lists of the top selling drugs. If data were not available from these sources, we used the company’s annual 10-K submission to the Securities and Exchange Commission or the settlement press releases.

\footnotetext{
important event that may have affected the firm's share price. The FTC does not disclose the list of settlements having terms it judges to have anticompetitive delays.

${ }^{27}$ The share price is taken to be the daily close adjusted for dividends and splits. We focus on the brand rather than generic stock-price movements following settlement because, substantively, it is the gain in expected profit for the brand from extension of the expected time during which it can sell as a monopoly that constitutes the threat to consumer welfare.

${ }^{28}$ We also downloaded data on the number of outstanding shares from the Compustat Industrial Files.
} 


\subsection{Trading Volume around the Announcement}

We examined trading volume in the days around the settlement announcements to provide insight into the extent of investors' reactions and to verify the accuracy of our classification of the settlement announcement dates. Following other event studies, we define “abnormal volume” as actual volume less an "expected volume” predicted from recent trading history. ${ }^{29}$ Elevated trading volume in the day of and days immediately following an announcement supports the idea that settlement announcements constitute news to which investors react. In order to combine measures of abnormal volume across firms, we measure abnormal volume in percentage terms.

We begin by estimating expected or normal trading volume at a firm as a function of market volume by estimating ordinary least squares regressions given in (1) for each firm $i:^{30}$

$$
\mathrm{NV}_{\mathrm{i}}^{\mathrm{t}}=\gamma_{i}+\delta_{i} \mathrm{MV}^{\mathrm{t}}+\mathrm{u}_{\mathrm{i}}^{\mathrm{t}}
$$

The dependent variable $\mathrm{NV}_{\mathrm{i}}^{\mathrm{t}}$ is the percent difference between firm i's trading volume on a given day $t$ and its mean volume in the 120 day period ending 30 days prior to the event. $\mathrm{MV}^{\mathrm{t}}$ is the analogous measure computed from the aggregate trading volume of all shares listed on NYSE, NASDAQ, and AMEX exchanges in the CRSP data base, which reports turnover. For each firm, the regression is estimated for the 120 trading days ending 30 days prior to the settlement announcement. Using the coefficients $\hat{\gamma}_{i}$ and $\widehat{\delta}_{i}$ estimated for each firm and observed levels of overall market volume, we can compute the expected normal volume for each firm, $\mathrm{E}\left[\mathrm{NV}_{\mathrm{i}}^{\mathrm{t}}\right]$, during the days around the settlement itself. We then compare this to actual volume, $\mathrm{V}_{\mathrm{i}}^{\mathrm{t}}$, (again measured in percentage terms in relation to the firm's mean volume from the 120 days ending 30

\footnotetext{
${ }^{29}$ Girotra, Terwiesch, and Ulrich (2007) use the same method and some theory behind it is explored by Tcak (1999).

${ }^{30}$ We refer to firm $i$ here for simplicity. Some firms were involved in multiple settlements and we calculate the abnormal volume and returns separately for each settlement.
} 
days prior to the settlement). Subtracting actual volume from expected normal volume yields our measure of abnormal volume, $A V_{i}^{\mathrm{t}}$, in percentage terms, for each firm $i$ and trading day $t$ around the settlement:

$$
A V_{i}^{t}=V_{i}^{t}-E\left[N V_{i}^{t}\right],
$$

where $\mathrm{E}\left[\mathrm{NV}_{\mathrm{i}}^{\mathrm{t}}\right]=\hat{\gamma}_{i}+\hat{\delta}_{i} \mathrm{MV}^{\mathrm{t}}$. To gauge whether there is a tendency for volume to move unusually when settlements are announced, we then examine the distribution of abnormal trading volumes for all the settlements in the period between five days before and five days after the event announcement. We conduct this analysis separately for the settlements with and without indication of a reverse payment.

\subsection{Event Study Methods}

Event studies examine the impact of a specific event on the stock price value of a firm, relying on the standard assumption that stock markets react quickly to news of an event bearing on the expected profits of the firm (Brown and Warner 1985; MacKinlay 1997). Applications of event-study methods are abundant in financial economics and related fields, including in the pharmaceutical industry. ${ }^{31}$

\subsubsection{Selection of event windows}

An "event window" defines the day or days during which the market is assumed to react to the new information. Event windows are typically chosen to be very short, ranging from the day of the event together with the day after (Panattoni 2011; Jacobo-Rubio, Turner, and Williams 2013) to a few days pre and post (Girotra, Terweisch, and Ulrich 2007). If the event window is

\footnotetext{
${ }^{31}$ See Panattoni (2011) and Jacobo-Rubio et al. (2013) for studies of the impact of litigation outcomes of 9 IV litigation. Other event studies of the pharmaceutical industry include Berndt, Conti and Huskamp (2011) and PérezRodríguez and Valcarcel (2012). Ellison and Mullin (2001) used event study methods to examine the effect of President Clinton's Health Care Reform on the pharmaceutical industry. Koijen, Philipson, and Uhlig (2014) examine how news of future government interventions in health care affect share prices of pharmaceutical and medical device firms.
} 
defined too narrowly, some of the effect of the news will be missed, whereas defining it too broadly adds noise to the measured effect (MacKinlay 1997). We estimate abnormal returns using a range of different event windows to ensure that results do not depend on the window choice. Using event windows that include days around the event date also allows for the possibility that investors learned of the settlement somewhat before or after the announcement date indicated in news sources or that the announcement date we identified for the event could be slightly inaccurate. In our notation, an event window $\left(-t_{1}, t_{2}\right)$ begins $t_{1}$ days before the event and ends $t_{2}$ days after. The window $(0,0)$ defines the event window to be only the event day itself. We consider a series of symmetric windows that begin one, two or three days before the event and end one, two or three days after. Finally, in the interest of gauging whether some part of the reaction to the news comes in the days before the settlement announcement, we also compare results using symmetric windows with results from asymmetric windows that begin on the event day and extend up to three days after. A finding of minimal difference in abnormal returns between the symmetric and asymmetric windows implies little stock-price reaction occurring in the days before the event.

\subsubsection{Estimating abnormal returns}

Measuring “abnormal returns" during an event window relies on estimation of the difference between the actual return and the expected return. The actual return on the stock of firm $i$ on day $t$, $\mathrm{R}_{\mathrm{i}}^{\mathrm{t}}$, is defined to be the percentage change in the closing price on the day in question over the previous day's close. We used three alternative models to estimate the expected return, ${ }^{32}$ all based on data for the 120 trading days ending 30 days prior to the event window. The first model, referred to as the Constant Mean Model, simply computes the

\footnotetext{
32 These models are commonly applied in event studies. For example, see Girotra, Terwiesch, and Ulrich (2007).
} 
expected return as the average daily return for the company's shares during the estimation

period:

$$
\mathrm{E}\left[\mathrm{R}_{\mathrm{i}}^{\mathrm{t}}\right]=\hat{\mu}_{i}
$$

The second, referred to as the Market Model, computes the expected return using fitted values from an OLS regression of $\mathrm{R}_{\mathrm{i}}^{\mathrm{t}}$, on the return to a market index $M \mathrm{R}^{\mathrm{t}}$ :

$$
\mathrm{E}\left[\mathrm{R}_{\mathrm{i}}^{\mathrm{t}}\right]=\widehat{\alpha}_{i}+\widehat{\beta}_{i} \mathrm{MR}^{\mathrm{t}}
$$

The value-weighted CRSP index, excluding dividends, was used to measure the market return in percentage terms. ${ }^{33}$ The third, the Fama-French Three-Factor Model, regresses the excess of the stock's return, $\mathrm{R}_{\mathrm{i}}^{\mathrm{t}}$, over the risk-free rate, $\mathrm{RF}^{\mathrm{t}}$, on three covariates: the excess return of the market index $\mathrm{MR}^{\mathrm{t}}$ over the risk-free rate, the excess return of small-cap over large-cap stocks, $\mathrm{SMB}^{\mathrm{t}}$, and the excess return of value over growth stocks, HMLt ${ }^{34}$ The fitted values are then used to compute the expected excess of the stock's return over the risk-free rate:

$$
\mathrm{E}\left[\mathrm{R}_{\mathrm{i}}^{\mathrm{t}}-\mathrm{RF}^{t}\right]=\widehat{\alpha}_{i}+\widehat{\beta}_{i}\left(\mathrm{MR}^{\mathrm{t}}-\mathrm{RF}^{\mathrm{t}}\right)+\widehat{\mathrm{s}}_{i} \mathrm{SMB}^{\mathrm{t}}+\hat{\mathrm{h}}_{i} \mathrm{HML}^{\mathrm{t}}
$$

Values of $\mathrm{RF}^{\mathrm{t}}, \mathrm{SMB}^{\mathrm{t}}$, and $\mathrm{HML}^{\mathrm{t}}$ are taken from the financial data library compiled by Kenneth French. $^{35}$

The abnormal return on day t is computed as the difference between the actual return, $\mathrm{R}_{\mathrm{i}}^{\mathrm{t}}$, and the expected return, $E\left[R_{i}^{t}\right]: A_{i}^{t}=R_{i}^{t}-E\left[R_{i}^{t}\right]$, and, for the Fama-French model, between the actual and expected return over the risk free rate, $E\left[R_{i}^{t}-R F^{t}\right]$, so: $A_{i}^{t}=\left[R_{i}^{t}-R F^{t}\right]-E\left[R_{i}^{t}-\right.$ $\mathrm{RF}^{t}$ ]. For multiday event windows, the cumulative abnormal return (CAR) is calculated by

\footnotetext{
${ }^{33}$ This is a broad market measure commonly used to compute market returns in event studies. It is a value-weighted index of shares trading on the New York Stock Exchange, the American Stock Exchange, and the NASDAQ exchange.

${ }^{34}$ The risk-free rate is the return on a short-term government bond, here the one-month U.S Treasury bill. The Three-Factor Model was put forth in Fama and French (1993) and is widely used in event studies.

${ }^{35}$ See Kenneth French's website, http://mba.tuck.dartmouth.edu/pages/faculty/ken.french/Data_Library/ff_factors.html (accessed January 27, 2014).
} 
summing the abnormal returns across the days in the event window. ${ }^{36}$ CARs are expressed as percentages, for example, the cumulative abnormal return during an event window might be 5 percent, meaning that in the event window, the firm's shares rose by 5 percent more than would have been expected.

\subsection{Hypotheses Tests}

To test the hypotheses about the nature of the settlements, we first compute mean cumulative abnormal returns associated with announcements of 9 IV settlements, using each of the three measures. We then examine whether mean CARs differ significantly from zero in the group of settlements with indication of a reverse payment and in the group of settlements without such an indication. Following standard event-study methods, for each model and event window, we determine whether the average estimated CAR is statistically different from zero using the variance of the distribution of CARs estimated in that case. ${ }^{37}$ The relevant test statistic is the average CAR divided by its standard error, where the latter is the standard deviation of the estimated CARs divided by the square root of the number of events in the sample. We then test whether CARs differ between settlements with and without an indication of a reverse-payment. This involves testing, for each model and each event window, whether the mean CARs are significantly different from each other. In these cases, the relevant test statistic is the difference in means divided by the standard error of the difference, the square root of the sum of the standard errors of the two estimates. ${ }^{38}$

\footnotetext{
${ }^{36}$ See MacKinlay (1997) for details on cumulating abnormal returns across multiple days and multiple securities, and for calculating variance and testing for statistical significance in these instances.

${ }^{37}$ See MacKinlay $(1997,24)$.

${ }^{38}$ The test allows for the possibility of unequal variances between the two groups. See e.g. Stata (2013, 2449).
} 


\section{Results}

\subsection{Abnormal Trading Volume}

Figure 1 shows the average abnormal trading volume around the announcement day for settlements with and without indication of a reverse payment. Abnormal volume was averaged separately for each day and the 95\% confidence interval around this daily average is also shown. For the settlements with indication of a reverse payment, the small elevation of trading volume was not statistically significant in the five days preceding the announcement of a settlement ( $\mathrm{p}>0.2$ ). On announcement day (Day 0) abnormal volume increased 203\% ( $\mathrm{p}=0.01$ ), and in the day following the announcement (Day 1) abnormal volume peaked at 313\% ( $\mathrm{p}=0.11)$. Trading levels fell in the second day following the announcement (Day 2) but were still significantly above normal albeit at a $10 \%$ level only $(\mathrm{p}=0.08)$. For the events without indication of a reverse payment, the abnormal trading volume was not elevated in any of the days surrounding the announcement ( $\mathrm{p}>0.2$ for all days). Based on the comparison of trading volumes, markets reacted differently to announcements of settlements with and without indication of a reverse payment.

\subsection{Average Cumulative Abnormal Returns}

Table 4 reports results for the Constant Mean, Market, and the Fama-French models for the 31 settlements with indication of a reverse payment. The abnormal return averaged $2.0 \%$ to $2.7 \%$ on the event day, depending on the model used, and significantly differed from zero at a 5\% level for the Market and Fama-French models and at a 10\% level in the Constant Mean model. For the three symmetric windows around the event day, the CARs ranged from $5.9 \%$ to $6.6 \%$ in all three models. In all cases the CARs were significantly different from zero at a $1 \%$ level. Results for the models with asymmetric windows excluding the pre-event days were 
similar to those with symmetric windows, implying little market anticipation just prior to the announcement. $^{39}$

Table 5 reports analogous results for the sample of 44 settlements without indication of a reverse payment. In all three models and for all event windows, the estimated CARs are less than $1.0 \%$, and none are statistically different from zero. ${ }^{40}$

In dollar terms, the estimated 6\% abnormal increase in the stock price following a settlement with indication of reverse payment corresponds to a \$316 million average increase in brand companies' market capitalization. The small reaction to settlements without indication of reverse payment corresponds to an $\$ 8$ million increase in market capitalization. ${ }^{41}$

Table 6 tests whether, for a given model and window, the mean cumulative abnormal return for settlements with indication of a reverse payment differed significantly from the mean for other settlements. For multiday event windows, cumulative abnormal returns for the reversepayment settlements are $5.5 \%$ to $6.0 \%$ higher than those for the other settlements and in all cases the difference is significantly different from zero. We regard settlements without an indication of reverse payment as constituting a control group of settlements reached for "normal” business reasons such as reducing business risk, avoiding future litigation costs, and eliminating distraction to management. Settlements with indication of a reverse payment could be made for the same reasons, but may also indicate the brand is paying for a delay in generic entry. The

\footnotetext{
${ }^{39}$ In one case, the company realized a cumulative abnormal return exceeding $40 \%$ on day 1 , which pulls up all estimates of cumulative abnormal returns when day 1 is in the event window by about 1.5 percentage points; nonetheless, CARs remain positive and statistically significant across all event windows, and p-values for tests of whether mean CARs for potential reverse-payment settlements differ from those of other settlements are qualitatively similar.

${ }^{40}$ In one case, the company realized a cumulative abnormal return exceeding $20 \%$ in days 0 and 1 , which pulls up estimated average CARs. Excluding this case lowers CARs in the various models and event windows by approximately $0.5 \%$, and $\mathrm{p}$-values for the hypothesis tests are qualitatively similar.

${ }^{41}$ The implied change in market capitalization is the cumulative abnormal return for each firm multiplied by its market capitalization on the day before the event window. Values of market capitalization are converted to 2013 dollars, using the Consumer Price Index.
} 
incremental stock price jump of approximately $6 \%$ upon announcement of a settlement with indication of a reverse payment compared to one without is consistent with the hypothesis that reverse payments buy an anticompetitive delay in generic entry.

The magnitude of the effect of a ๆ IV settlement on the company's share price may differ according to the relative importance of the drug in the company's expected future revenues. To investigate this possibility, we use the share of the drug's sales in the brand company's operating revenues as a proxy for its relative importance, recognizing that this measure correlates imperfectly with its share of expected future net revenues. ${ }^{42}$ We repeated the analysis from Table 6 including only drugs for which sales represented $5 \%$ or more, or alternatively, $10 \%$ or more of the companies' total operating revenues (35 and 28 drugs, respectively). Table 7 shows results for the widest event window $(-3,3)$ for all three model specifications; the pattern of results for other windows is qualitatively similar.

Confining our analysis to settlements where the drug accounts for $5 \%$ or more of the total company's sales reduces the sample to 35 cases (23 with indication of a reverse payment, 12 without), about half of the original sample. ${ }^{43}$ Compared to the full sample results, cumulative abnormal returns are higher for both groups. For settlements above the $5 \%$ cutoff with indication of a reverse payment, average cumulative abnormal returns range from $8.4 \%$ to $8.7 \%$, depending on the model, compared to our earlier findings of $6.1 \%$ to $6.6 \%$ for all settlements with indication of a reverse payment. For the other settlements above the $5 \%$ cutoff, average CARs are $0.2 \%$ to $1.6 \%$, compared to our earlier findings ranging from $-0.1 \%$ to $0.7 \%$ for all

\footnotetext{
${ }^{42}$ Notably, a drug close to its patent expiry is worth less in this respect than one with many years remaining. See Panattoni $(2013,136)$ for discussion.

${ }^{43}$ Note that as we introduce sales cutoffs, the share of settlements with an indication of a reverse payment rises in relation to the total settlements. This implies that brands are more likely to make a reverse payment for a more important drug.
} 
settlements with no indication of reverse payment, but here too the CARs are not significantly different from zero. In all three models, the average CAR for settlements with an indication of a reverse payment was significantly above that for other settlements, by $6.8 \%$ to $8.5 \%$. In results not shown, this pattern of CARs was similar across all multiday event windows, but differences between payments with and without indications were statistically significant at the $10 \%$ level only for some of the shorter windows.

Further restricting the analysis to cases where settlements concerned drugs making up at least $10 \%$ of the brand manufacturer's sales leaves only 21 cases with an indication of a reverse payment and 7 without, cutting the sample to about a third of the original size. Here again we find large and statistically significant CARs for settlements with indications of reverse payments in a range of $9.2 \%$ to $9.4 \%$. Average CARs for the other settlements range from $1.5 \%$ to $3 \%$, but remain insignificantly different from zero. We continued to find sizable differences in cumulative abnormal returns between settlements with and without an indication of reverse payment for this smaller sample, but here they are not statistically significant, which is unsurprising in view of the small sample size.

In sum, the results indicate that investors tend to view news of settlements with indications of reverse payments as improving the expected profits of the brand company, leading to a statistically significant bump in stock price upon announcement of a settlement with indication of a reverse payment. The increment in stock price jump remains when stock price movements with reverse-payment announcements are compared to announcement of settlements with no indication of a reverse payment. These results support the hypothesis that reverse payment settlements delay generic entry and are anticompetitive. 


\section{Conclusion}

This paper uses publicly available data and event-study methods to test how the announcement of a patent-dispute settlement between a brand and generic manufacturer affects the stock price of the brand. We distinguish between settlements for which announcements do and do not include indication of a possible "reverse payment" from the brand (the plaintiff) to the generic (the defendant) in the suit. As a group, announcements of settlements with no indication of a reverse payment did not impact brand stock prices, whereas announcement of settlements with indication of reverse payment had a significant positive effect on stock prices of approximately 6\%. Our results support the FTC's contention that brands use reverse payments to buy more time for selling without competition from generics than they would get on average from following through with litigation. As Shapiro (2003b) and others have argued, a settlement that increases the expected duration of monopoly harms consumers and is anticompetitive.

The analysis presented in the current paper makes no claim about the economic effect or legality of any individual I IV settlement, but rather evaluates average effects of settlements with and without indications of reverse payments. To fully evaluate whether an individual settlement is anticompetitive would require detailed information on the settlement's terms, which is not available in documents available to the public. Given that our classification relies on the information on settlement terms that firms opt to disclose publicly, it is potentially subject to measurement error in both directions: some settlements we classified as having an indication of reverse payment may not transfer value to the generic, and some that did not disclose information suggesting such a transfer may in fact have done so.

Our estimated effect of a $6 \%$ average abnormal return after settlements with reverse payments is similar to Panattoni's (2011) estimate, discussed earlier, on how court decisions that 
resolve II IV disputes affect brand companies’ share prices. She found that, following announcement of a court decision upholding the brand's patent claim, the share price of the brand company rose approximately $4 \% .{ }^{44}$ Despite their similarity, the effects are not directly comparable. The agreed-upon entry dates in our reverse payment settlements fall before the date of final patent expiry, so in principle one might expect a settlement to improve the expected profits of the brand less than a straight court victory. However, the brand may be more likely to enter into a reverse-payment settlement in patent litigation over a drug accounting for a large percentage of its expected future earnings. Indeed, for the settlements in our sample that had indications of reverse payments, the average ratio of sales of the drug involved in the settlement to the company's total was approximately twice as large as the cases that reached a decision in Panattoni’s sample. ${ }^{45}$

The main difference between analysis of court decisions and settlements is the legal basis of the extension of time for the brand to sell as a monopolist. In a court decision, the brand has earned the right by virtue of the innovativeness of the patent-protected product. In the case of a reverse-payment settlement, the brand is buying more time irrespective of the merits of the underlying patent.

\footnotetext{
${ }^{44}$ Jacobo-Rubio, Turner, and Williams (2013) included a wider range of cases involving drugs with smaller average sales, and found somewhat smaller effects.

${ }^{45}$ See Panattoni’s $(2011,139)$ Table 8 - Panel C.
} 


\section{References}

Berle, Adolf, and Gardiner Means. 1932. The Modern Corporation and Private Property. New York: Harcourt Brace.

Berndt, Ernst R., and Murray L. Aitken. 2011. “Brand Loyalty, Generic Entry and Price Competition in Pharmaceuticals in the Quarter Century after the 1984 Waxman-Hatch Legislation.” International Journal of the Economics of Business 18(2): 177-201.

Berndt, Ernst, R., Rena M. Conti, and Haiden A. Huskamp. 2001. “The Effect of FDA Advisories on Branded Pharmaceutical Firms' Valuations and Promotion Efforts.” Working Paper no. 17528. National Bureau of Economic Research, Cambridge, MA.

Brown, Stephen J., and Jerold B. Warner. 1985. "Using Daily Stock Returns: The Case of Event Studies.” Journal of Financial Economics 14: 3-31.

Bulow, Jeremy. 2004. “The Gaming of Pharmaceutical Patents.” 145-187 in Innovation Policy and the Economy, edited by Adam B. Jaffe, Josh Lerner, and Scott Stern. Cambridge: MIT Press.

Campbell, John, Andrew Lo, and A. Craig Mackinlay. 1997. The Econometrics of Financial Markets. Princeton, NJ: Princeton University Press.

Congressional Budget Office. 1998. “How Increased Competition from Generic Drugs has Affected Prices and Returns in the Pharmaceutical Industry.” http://www.cbo.gov/publication/10938 (last updated July 1, 1998).

Cotter, Thomas F. 2003. “Refining the 'Presumptive Illegality’ Approach to Settlements of Patent Disputes Involving Reverse Payments: A Commentary on Hovenkamp, Janis \& Lemley.” Minnesota Law Review 87(6): 1789-1816. 
Cotter, Thomas F. 2004. “Antitrust Implications of Patent Settlements Involving Reverse Payments: Defending a Rebuttable Presumption of Illegality in Light of Some Recent Scholarship.” Antitrust Law Journal 71(3): 1069-097.

Dickey, Brett, Jonathan Orszag, and Laura Tyson. 2010. “An Economic Assessment of Patent Settlements in the Pharmaceutical Industry.” Annals of Health Law 19(2): 367-400.

Edlin, Aaron, Scott Hemphill, Herbert Hovenkamp, and Carl Shapiro. 2013. “Activating Actavis.” Antitrust 28(1): 16-23.

Elhauge, Einer, and Alex Krueger. 2012. “Solving the Patent Settlement Puzzle.” Texas Law Review 91: 283-300.

Ellison, Sara F., and Wallace P. Mullin. 2001. “Gradual Incorporation of Information: Pharmaceutical Stocks and the Evolution of President Clinton's Health Care Reform.” Journal of Law and Economics 44: 89-129.

Fama, Eugene F., and Kenneth R. French. 1993. "Common Risk Factors in Returns on Stocks and Bonds.” Journal of Financial Economics 33: 3-56.

Fama, Eugene F., and Michael C. Jensen. 1983. “Separation of Ownership and Control.” Journal of Law and Economics 26: 301-325.

Federal Trade Commission. 2007. "FTC Provides Senate Testimony on Anticompetitive Patent Settlements in the U.S. Pharmaceutical Industry.” http://www.ftc.gov/news-events/pressreleases/2007/01/ftc-provides-senate-testimony-anticompetitive-patent-settlements (last updated January 17, 2007).

Federal Trade Commission. 2010. "Pay-for-Delay: How Drug Company Pay-Offs Cost Consumers Billions.” http://www.ftc.gov/reports/pay-delay-how-drug-company-payoffs-cost-consumers-billions-federal-trade-commission-staff (last updated January 2010). 
Federal Trade Commission. 2011. “Authorized Generic Drugs: Short-Term Effects and LongTerm Impact.” http://www.ftc.gov/opa/2011/08/genericdrugs.shtm (last updated August 31, 2011).

Federal Trade Commission. 2013. “Agreements Filed with the Federal Trade Commission under the Medicare Prescription Drug, Improvement, and Modernization Act of 2003: Overview of Agreements Filed in Fiscal Year 2012: A Report by the Bureau of Competition.” http://www.ftc.gov/reports/agreements-filed-federal-trade-commissionunder-medicare-prescription-drug-improvement (last updated January 2013).

Food and Drug Administration. 2014. "Paragraph IV Patent Certifications.” http://www.fda.gov/drugs/developmentapprovalprocess/howdrugsaredevelopedandappro ved/approvalapplications/abbreviatednewdrugapplicationandagenerics/ucm047676.htm.

Girotra, Karen, Christian Terwiesch, and Karl T. Ulrich. 2007. "Valuing R\&D Projects in a Portfolio: Evidence from the Pharmaceutical Industry.” Management Science 53(9): $1452-1466$.

Green, Daniel. 1995. “Glaxo Shares Rise as it Settles Patent Case.” Financial Times, October 24. Greene, Adam, and D. Dewey Steadman. 2010. “Pharmaceuticals: Analyzing Litigation Success Rates.” http://amlawdaily.typepad.com/pharmareport.pdf.

Generic Pharmaceutical Association. 2006. "Re: Authorized Generic Drug Study: FTC Project No. P062105.” http://www.ftc.gov/os/comments/genericdrugstudy3/062806gpha.pdf.

Harris, Barry C., Kevin M. Murphy, Robert D. Willig \& Matthew B. Wright. 2014. “Activating Actavis: A More Complete Story.” Antitrust Magazine 28(2): 83-89. 
Hemphill, C. Scott. 2009. “An Aggregate Approach to Antitrust: Using New Data and Rulemaking to Preserve Drug Competition.” Columbia Law Review 109(4): 629-687. Hemphill, C. Scott. 2014. “Unjustified Delays in Generic Drug Competition.” Organization for Economic Cooperation and Development, White Paper on Generic Pharmaceuticals, DAF/COMP/WD(2014)76.

Hovenkamp, Herbert, Mark Janis, and Mark A. Lemley. 2003. “Anticompetitive Settlement of Intellectual Property Disputes.” Minnesota Law Review 87: 1719-1766.

IMS Institute for Healthcare Informatics. 2013. “Impact of Patent Settlements on Drug Costs: Estimation of Savings.” http://www.imshealth.com/deployedfiles/imshealth/Global/Content/Corporate/IMS\%20In stitute/Impact_of_Patent_Settlements_on\%20Drug_Costs.pdf (last updated June 2013). Jacobo-Rubio, Ruben, John L. Turner, and Jonathan Williams. 2013. “Pharmaceutical Patent Litigation: Measuring the Value of Generic Entry Rights and Brand Deterrence.” Unpublished manuscript. University of Georgia, Department of Economics, June.

Jensen, Michael C., and William H. Meckling. 1976. “Theory of the Firm: Managerial Behavior, Agency Costs and Ownership Structure.” Journal of Financial Economics 3(4): 305-260. Koijen, Ralph S.J., Tomas J. Philipson, and Harald Uhlig. 2014. “Financial Health Economics.” Working Paper no. 20075. National Bureau of Economic Research, Cambridge, MA. Leffler, Keith, and Cristofer Leffler. 2003. “The Probabilistic Nature of Patent Rights: In Response to Kevin McDonald.” Antitrust 17: 77-83.

MacKinlay, A. Craig. 1997. "Event Studies in Economics and Finance.” Journal of Economic Literature 35: 13-39. 
Meland, Marius. 2005. “Kos, Barr Settle Niaspan Patent Litigation with Unusual Deal.” http://www.law360.com/articles/3283/kos-barr-settle-niaspan-patent-litigation-withunusual-deal (last updated April 13, 2005).

Panattoni, Laura E. 2011. “The Effect of Paragraph IV Decisions and Generic Entry before Patent Expiration on Brand Pharmaceutical Firms.” Journal of Health Economics 30(1): 126-145.

Pérez-Rodríguez, Jorge V., and Beatriz G.L. Valcarcel. 2012. “Do Product Innovation and News about the R\&D Process Produce Large Price Changes and Overreaction? The Case of Pharmaceutical Stock Prices.” Applied Economics 44(17): 2217-2229.

PR Newswire. 2006. "Par Pharmaceutical Announces Agreement with GlaxoSmithKline to Settle Imitrex® Injection Patent Litigation: Settlement Agreement with GSK Resolves Imitrex ${ }^{\circledR}$ Injection Patent Litigation and Permits Par to Launch Generic Version in 2008. November 13.

Shapiro, Carl. 2003a. “Antitrust Analysis of Patent Settlements between Rivals.” Antitrust 70-77. Shapiro, Carl. 2003b. “Antitrust Limits to Patent Settlements.” RAND Journal of Economics. 34(2): 391-411.

Stata. 2013. Stata Base Reference Manual, Release 13. College Station, TX: Stata Press.

Tcak, Paula A. 1999. “A Trading Volume Benchmark: Theory and Evidence.” Journal of Financial and Quantitative Analysis 34(1): 89-114.

U.S. PIRG. 2013. “Top Twenty Pay-for-Delay Drugs: How Drug Industry Payoffs Delay Generics, Inflate Prices, and Hurt Consumers.” http://www.uspirg.org/sites/pirg/files/reports/Top_Twenty_Pay_For_Delay_Drugs_USPI RG.pdf (last updated July 2013). 
Washington Business Information, Inc. 2012. “Mylan, Teva Settle Nuvigil Dispute Allowing Generic Launch in 2016.” May 9.

Willig, Robert D., and John P. Bigelow. 2004. “Antitrust Policy toward Agreements that Settle Patent Litigation.” The Antitrust Bulletin 49: 655-698.

Yu, Xiang, and Anjan Chatterji. 2011. "Why Brand Pharmaceutical Companies Choose to Pay Generics in Settling Patent Disputes: A Systematic Evaluation of the Asymmetric Risks in Litigation.” Northwestern Journal of Technology and Intellectual Property 10(2): 1936. 
Table 1. Excerpt examples from press releases announcing settlements with and without indication of reverse payment

\begin{tabular}{|c|c|}
\hline Indication of reverse payment & No indication of reverse payment \\
\hline $\begin{array}{l}\text { "The deal was sweetened by giving rights to } \\
\text { Genpharm to sell Zantac in the UK, Canada } \\
\text { and Australia from } 1996 \text { and 1997, depending } \\
\text { on the country. Glaxo Wellcome has also } \\
\text { agreed to a series of cash payments to } \\
\text { Genpharm 'which is not considered as material to } \\
\text { Glaxo Wellcome'. Litigation between the two in } \\
\text { Canada and the UK is being discontinued” } \\
\text { (Green, 1995). } \\
\text { "Under the seven-year deal, Barr subsidiary } \\
\text { Duramed Pharmaceuticals will co-promote } \\
\text { Niaspan and Advicor -- as well as any future } \\
\text { dosages or modified versions -- to obstetricians, } \\
\text { gynecologists and other women's healthcare } \\
\text { practitioners in exchange for royalties on } \\
\text { quarterly and yearly sales. Kos will help train a } \\
\text { Duramed sales force of } 40 \text { to begin marketing } \\
\text { both Kos and Duramed products by mid-2005, } \\
\text { the companies said. The agreement also permits } \\
\text { Barr to launch generic versions of Niaspan and } \\
\text { Advicor beginning in September } 2013 \text {, four } \\
\text { years before Kos' last patent expires” (Meland, } \\
2005 \text { ). }\end{array}$ & $\begin{array}{l}\text { "Par Pharmaceutical Companies, Inc. } \\
\text { (NYSE:PRX) today announced that its partner, } \\
\text { Spectrum Pharmaceuticals, Inc., has entered into a } \\
\text { settlement agreement with GlaxoSmithKline } \\
\text { (GSK) that resolves U.S. patent litigation related } \\
\text { to GSK's Imitrex(R) Injection, thereby eliminating } \\
\text { the inherent uncertainty and costs of litigation. } \\
\text { The confidential terms of the settlement, which } \\
\text { remain subject to government review, permit Par } \\
\text { to sell generic versions of certain sumatriptan } \\
\text { injection products with an expected launch date } \\
\text { during GSK's sumatriptan pediatric exclusivity } \\
\text { period which begins on August 6, 2008, but with } \\
\text { the launch occurring not later than November” } \\
\text { 2008 (PR Newswire, 2006). } \\
\text { "Mylan can launch its generic version of Teva } \\
\text { Pharmaceutical's sleep drug Nuvigil in June 2016 } \\
\text { under a settlement agreement between the two } \\
\text { companies announced April 30. Mylan is also } \\
\text { claiming it will have } 180 \text { days of market } \\
\text { exclusivity for the generic as the first ANDA filer. } \\
\text { The agreement is subject to review by the FTC” } \\
\text { (Washington Business Information, Inc., 2012). }\end{array}$ \\
\hline
\end{tabular}

Note: Bolded information used to identify settlements with an indication of a reverse payment. 
Table 2: Information on drugs in settlements with indication of a potential reverse payment

\begin{tabular}{|c|c|c|c|c|c|}
\hline Announcement & Brand Name & Generic Name & Primarily used for: & $\begin{array}{l}\text { Annual Sales } \\
\text { (millions of } \\
\text { '13 US\$) }\end{array}$ & $\begin{array}{l}\text { Last Patent } \\
\text { Expiration Date }\end{array}$ \\
\hline 3/9/1993 & Nolvadex & tamoxifen & Breast cancer & 425 & $2002^{b}$ \\
\hline 10/23/1995 & Zantac & ranitidine & Ulcers, acid reflux & 5,478 & $2002^{\mathrm{b}}$ \\
\hline 9/11/2003 & Ovcon & norethindrone/ethinyl estradiol & Contraception & 77 & \\
\hline $2 / 17 / 2005$ & Lamictal & lamotrigine & Seizures, mood disorders & 1,224 & 7/29/2012 \\
\hline $4 / 13 / 2005$ & Niaspan & niacin & Abnormal cholesterol & 452 & $5 / 15 / 2018$ \\
\hline $12 / 9 / 2005$ & Provigil & modafinil & Sleep disorders & 590 & $5 / 29 / 2024$ \\
\hline 3/21/2006 & Plavix ${ }^{c}$ & clopidogrel & Prevention of blood clots & 2,583 & $12 / 10 / 2019$ \\
\hline $8 / 14 / 2006$ & Adderall XR & amphetamine/dextroamphetamine & Attention deficit hyperactivity disorder & 1,310 & 4/21/2019 \\
\hline 3/5/2007 & Wellbutrin $\mathrm{XL}^{\mathrm{c}}$ & bupropion & Depression & 1,104 & 10/30/2018 \\
\hline $7 / 26 / 2007$ & Valtrex & valaciclovir & Herpes & 1,552 & 7/19/2016 \\
\hline $12 / 4 / 2007$ & Cardizem LA & diltiazem & Hypertension & 77 & $2 / 25 / 2021$ \\
\hline $4 / 15 / 2008$ & Nexium & esomeprazole & Acid reflux, heartburn, ulcers & 5,327 & $5 / 3 / 2020$ \\
\hline $6 / 5 / 2008$ & Depakote ER & divalproex sodium & Epilepsy, bipolar disorder & 769 & $6 / 18 / 2019$ \\
\hline $6 / 18 / 2008$ & Lipitor/Caduet $^{\mathrm{d}}$ & atorvastatin & High cholesterol & 6,534 & $1 / 8 / 2017$ \\
\hline $11 / 25 / 2008$ & Pulmicort & budesonide & Asthma attacks & 723 & 6/23/2019 \\
\hline 12/1/2008 & Solodyn & minocycline & Acne, skin conditions & 351 & 3/7/2027 \\
\hline $12 / 23 / 2008$ & Clarinex- $\mathrm{D}^{\mathrm{C}}$ & desloratadine & Allergies & 260 & $6 / 19 / 2021$ \\
\hline 1/12/2009 & Loestrin & ethinyl estradiol/norethindrone & Contraception & 289 & 2/2/2029 \\
\hline $4 / 14 / 2009$ & Vanos & fluocinonide & Skin conditions & 29 & $1 / 7 / 2023$ \\
\hline $6 / 8 / 2010$ & Opana ER ${ }^{\mathrm{c}}$ & oxymorphone hydrochloride & Moderate to severe pain & 391 & $7 / 10 / 2029$ \\
\hline $8 / 28 / 2010$ & Luvox CR & fluvoxamine maleate & Obsessive compulsive disorder & 29 & $5 / 10 / 2020$ \\
\hline 9/30/2010 & OsmoPrep & $\begin{array}{l}\text { sodium biphosphate/sodium } \\
\text { phosphate }\end{array}$ & Pre-colonoscopy & 58 & 6/22/2028 \\
\hline 4/4/2011 & Cubicin & daptomycin & Bacterial infections & 723 & $11 / 28 / 2020$ \\
\hline 10/3/2011 & Angiomax & bivalirudin & Prevents blood clots during angioplasty & 480 & $1 / 27 / 2029$ \\
\hline $5 / 29 / 2012$ & Lidoderm & lidocaine & Topical anesthetic & 1,305 & $10 / 27 / 2015$ \\
\hline $7 / 17 / 2012$ & Silenor & doxepin & Depression, insomnia & 12 & 8/24/2027 \\
\hline 11/28/2012 & Ofirmev INJ & acetaminophen & Analgesic injection & 43 & 6/6/2021 \\
\hline
\end{tabular}

${ }^{\mathrm{a}}$ Drug sales at announcement converted to 2013 dollars using the Consumer Price Index for all urban consumers. ${ }^{\mathrm{b}}$ Patent expiration date taken from press release instead of Orange Book. 'Settlement affected two brand companies. ${ }^{\mathrm{d}}$ Settlement covered two drugs; the table provides data for the drug with higher sales. 
Table 3: Information on drugs in settlements without indication of a reverse payment

\begin{tabular}{|c|c|c|c|c|c|}
\hline Announcement & Brand Name & Generic Name & Primarily used for: & $\begin{array}{l}\text { Annual Sales } \\
\text { (millions of } \\
\left.{ }^{\prime} 13 \text { US\$) }\right)^{\mathrm{a}}\end{array}$ & $\begin{array}{c}\text { Last Patent } \\
\text { Expiration Date }\end{array}$ \\
\hline 7/31/2003 & Ortho Tri-cyclen & norgestimate/ethinyl estradiol & Contraception & 1,065 & $3 / 25 / 2004^{b}$ \\
\hline 10/19/2005 & Effexor XR & venlafaxine & Depression, anxiety & 2,634 & 9/20/2017 \\
\hline $11 / 13 / 2006$ & Imitrex injection & sumatriptan succinate & Migraines & 993 & 3/10/2014 \\
\hline 7/19/2007 & Ultracet & Tramadol & Severe pain & 389 & $2011^{\mathrm{b}}$ \\
\hline $10 / 15 / 2007$ & Diastat & diazepam rectal gel & Seizures & 83 & 9/17/2013 \\
\hline $10 / 22 / 2007$ & Adenoscan & adenosine injection & Cardiac imaging & 181 & 3/24/2015 \\
\hline $10 / 23 / 2007$ & Paxil CR & paroxetine hydrochloride & Depression, anxiety & 312 & 9/17/2017 \\
\hline 12/6/2007 & Exelon & rivastigmine tartrate & Dementia & 222 & $2 / 11 / 2014$ \\
\hline $11 / 19 / 2008$ & Nasacort & triamcinolone & Allergies & 637 & $2016^{\mathrm{b}}$ \\
\hline 12/2/2008 & Femara & letrozole & Breast cancer & 401 & $2011^{\mathrm{b}}$ \\
\hline $1 / 20 / 2009$ & Clarinex $^{\mathrm{c}}$ & desloratadine & Allergies & 196 & $6 / 19 / 2021$ \\
\hline $4 / 21 / 2009$ & Rythmol SR & propafenone & Irregular heartbeat & 129 & $10 / 28 / 2014$ \\
\hline 7/24/2009 & Ortho Tri-Cyclen Lo & norgestimate/ethinyl estradiol & Contraception & 271 & 12/9/2019 \\
\hline $10 / 23 / 2009$ & Namenda & memantine & Alzheimer's disease & 725 & $4 / 11 / 2015$ \\
\hline $10 / 28 / 2009$ & Oxytrol & oxybutynin & Overactive bladder & 42 & $4 / 26 / 2020$ \\
\hline $11 / 30 / 2009$ & Tricor & fenofibrate & High cholesterol & 1,325 & $2 / 21 / 2023$ \\
\hline $2 / 2 / 2010$ & Focalin $^{\mathrm{c}}$ & dexmethylphenidate & Attention deficit hyperactivity disorder & 444 & $11 / 1 / 2019$ \\
\hline $4 / 5 / 2010$ & Luxiq/ Evoclin ${ }^{\mathrm{d}}$ & betamethasone valerate & Skin conditions & 87 & $5 / 24 / 2017$ \\
\hline $4 / 12 / 2010$ & Malarone & atovaquone/ proguanil & Malaria & 60 & $5 / 25 / 2014$ \\
\hline $5 / 10 / 2010$ & Zetia & ezetimibe & High cholesterol & 1,051 & 4/30/2026 \\
\hline $5 / 27 / 2010$ & Combivir & lamivudine/zidovudine & HIV complications & 174 & 11/18/2016 \\
\hline $7 / 24 / 2013$ & Tarceva & erlotinib & Cancer & 661 & 11/9/2020 \\
\hline $6 / 22 / 2011$ & Fosrenol & lanthanum carbonate & End stage renal disease & 173 & 8/26/2024 \\
\hline 9/30/2011 & Welchol & colesevelam & High cholesterol & 404 & $10 / 17 / 2022$ \\
\hline 9/30/2011 & Seroquel XR & quetiapine fumarate & Depression & 1,046 & 5/28/2017 \\
\hline $10 / 20 / 2011$ & Trilipix & fenofibric acid & High cholesterol & 1,325 & $1 / 7 / 2025$ \\
\hline
\end{tabular}

${ }^{a}$ Drug sales at announcement converted to 2013 dollars using the Consumer Price Index for all urban consumers. ${ }^{b}$ Patent expiration date taken from press releases instead of Orange Book. ${ }^{\mathrm{c}}$ Settlement affected two brand companies. ${ }^{\mathrm{d}}$ Settlement covered two drugs; the table provides data for both drugs. 
Table 3 (continued): Information on drugs in settlements without indication of a reverse payment

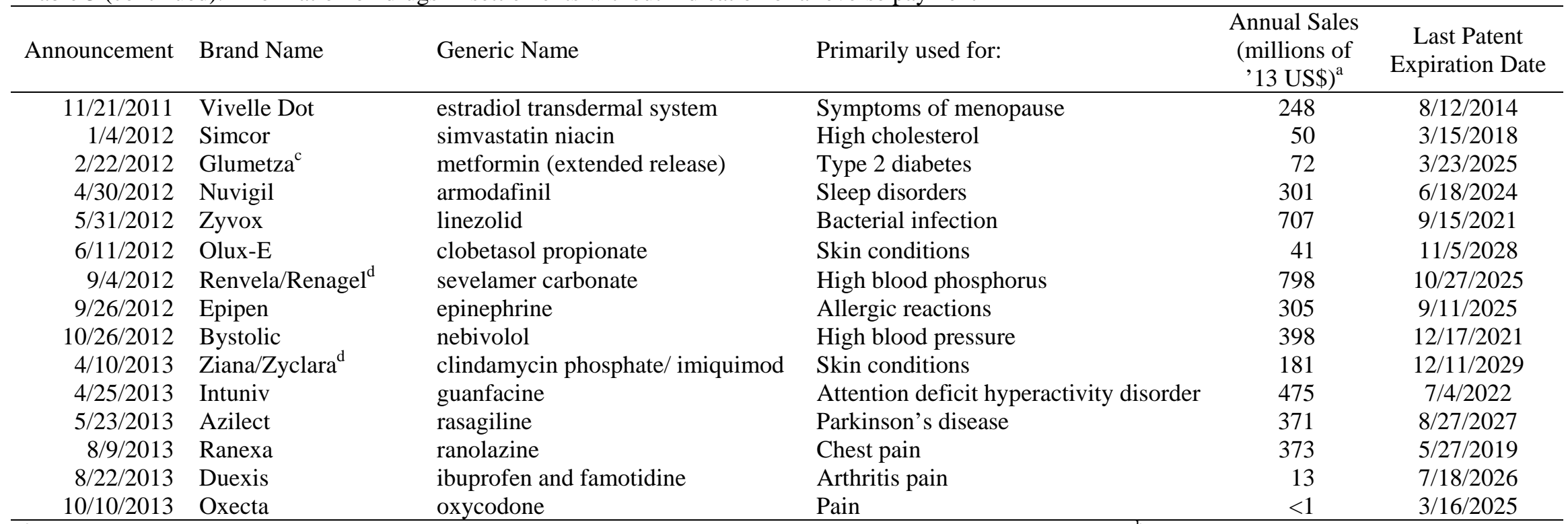

${ }^{a}$ Drug sales at announcement converted to 2013 dollars using the Consumer Price Index for all urban consumers. ${ }^{b}$ Patent expiration date taken from press releases instead of Orange Book. ${ }^{\mathrm{c}}$ Settlement affected two brand companies. ${ }^{\mathrm{d}}$ Settlement covered two drugs; the table provides data for both drugs. 
Table 4. Event study results for settlements with indication of a potential reverse payment $(n=31)$

\begin{tabular}{|c|c|c|c|}
\hline $\begin{array}{c}\text { Event } \\
\text { window }\end{array}$ & $\begin{array}{c}\text { Cumulative } \\
\text { abnormal } \\
\text { return }\end{array}$ & T-statistic & $\begin{array}{c}\mathrm{p} \text {-value for } \\
\mathrm{H}_{0} \text { : diff }=0\end{array}$ \\
\hline \multicolumn{4}{|c|}{ Constant Mean Model } \\
\hline$(0,0)$ & $2.0 \%$ & 1.73 & 0.094 \\
\hline$(-1,1)$ & $6.3 \%$ & 2.83 & 0.008 \\
\hline$(-2,2)$ & $6.6 \%$ & 3.01 & 0.005 \\
\hline$(-3,3)$ & $6.6 \%$ & 3.12 & 0.004 \\
\hline$(0,1)$ & $6.4 \%$ & 2.91 & 0.007 \\
\hline$(0,2)$ & $6.6 \%$ & 3.02 & 0.005 \\
\hline$(0,3)$ & $6.2 \%$ & 3.23 & 0.003 \\
\hline \multicolumn{4}{|l|}{ Market Model } \\
\hline$(0,0)$ & $2.6 \%$ & 2.29 & 0.029 \\
\hline$(-1,1)$ & $6.5 \%$ & 2.92 & 0.007 \\
\hline$(-2,2)$ & $6.3 \%$ & 2.96 & 0.006 \\
\hline$(-3,3)$ & $6.4 \%$ & 3.17 & 0.003 \\
\hline$(0,1)$ & $6.5 \%$ & 2.97 & 0.006 \\
\hline$(0,2)$ & $6.4 \%$ & 2.95 & 0.006 \\
\hline$(0,3)$ & $6.0 \%$ & 3.25 & 0.003 \\
\hline \multicolumn{4}{|c|}{ Fama-French Three-Factor Model } \\
\hline$(0,0)$ & $2.7 \%$ & 2.36 & 0.025 \\
\hline$(-1,1)$ & $6.5 \%$ & 2.93 & 0.006 \\
\hline$(-2,2)$ & $5.9 \%$ & 2.87 & 0.007 \\
\hline$(-3,3)$ & $6.1 \%$ & 3.06 & 0.005 \\
\hline$(0,1)$ & $6.6 \%$ & 3.03 & 0.005 \\
\hline$(0,2)$ & $6.4 \%$ & 3.01 & 0.005 \\
\hline$(0,3)$ & $6.0 \%$ & 3.33 & 0.002 \\
\hline
\end{tabular}


Table 5. Event study results for settlements without indication of a reverse payment $(n=44)$

\begin{tabular}{|c|c|c|c|}
\hline $\begin{array}{c}\text { Event } \\
\text { window }\end{array}$ & $\begin{array}{c}\text { Cumulative } \\
\text { abnormal } \\
\text { return }\end{array}$ & T-statistic & $\begin{array}{l}\mathrm{p} \text {-value for } \\
\mathrm{H}_{0} \text { : diff }=0\end{array}$ \\
\hline \multicolumn{4}{|c|}{ Constant Mean Model } \\
\hline$(0,0)$ & $0.5 \%$ & 0.81 & 0.422 \\
\hline$(-1,1)$ & $0.7 \%$ & 0.99 & 0.326 \\
\hline$(-2,2)$ & $0.0 \%$ & 0.02 & 0.984 \\
\hline$(-3,3)$ & $-0.1 \%$ & -0.16 & 0.870 \\
\hline$(0,1)$ & $0.8 \%$ & 1.06 & 0.297 \\
\hline$(0,2)$ & $0.5 \%$ & 0.68 & 0.500 \\
\hline$(0,3)$ & $0.4 \%$ & 0.61 & 0.544 \\
\hline \multicolumn{4}{|l|}{ Market Model } \\
\hline$(0,0)$ & $0.6 \%$ & 1.19 & 0.239 \\
\hline$(-1,1)$ & $0.8 \%$ & 1.38 & 0.176 \\
\hline$(-2,2)$ & $0.4 \%$ & 0.56 & 0.581 \\
\hline$(-3,3)$ & $0.3 \%$ & 0.42 & 0.675 \\
\hline$(0,1)$ & $0.9 \%$ & 1.37 & 0.179 \\
\hline$(0,2)$ & $0.6 \%$ & 0.90 & 0.372 \\
\hline$(0,3)$ & $0.4 \%$ & 0.62 & 0.535 \\
\hline \multicolumn{4}{|c|}{ Fama-French Three-Factor Model } \\
\hline$(0,0)$ & $0.7 \%$ & 1.27 & 0.211 \\
\hline$(-1,1)$ & $0.9 \%$ & 1.35 & 0.183 \\
\hline$(-2,2)$ & $0.7 \%$ & 0.90 & 0.375 \\
\hline$(-3,3)$ & $0.7 \%$ & 0.88 & 0.385 \\
\hline$(0,1)$ & $0.8 \%$ & 1.32 & 0.194 \\
\hline$(0,2)$ & $0.7 \%$ & 0.96 & 0.343 \\
\hline$(0,3)$ & $0.5 \%$ & 0.80 & 0.428 \\
\hline
\end{tabular}


Table 6. Tests of differences for settlements with and without indication of a reverse payment

\begin{tabular}{|c|c|c|c|c|c|}
\hline \multirow{4}{*}{ Constant Mean Model } & \multicolumn{4}{|c|}{ Event window } & \\
\hline & \multirow[t]{2}{*}{$(0,0)$} & \multirow{2}{*}{$(0,1)$} & \multirow{2}{*}{$(0,2)$} & \multirow[t]{2}{*}{$(0,3)$} & \\
\hline & & & & & $\mathrm{N}$ \\
\hline & \multicolumn{5}{|c|}{ Mean CAR for: } \\
\hline $\begin{array}{l}\text { Settlements with } \\
\text { reverse payments }\end{array}$ & $\begin{array}{c}2.0 \% \\
(0.094)\end{array}$ & $\begin{array}{c}6.4 \% \\
(0.007)\end{array}$ & $\begin{array}{c}6.6 \% \\
(0.005)\end{array}$ & $\begin{array}{c}6.2 \% \\
(0.003)\end{array}$ & 31 \\
\hline Others & $\begin{array}{c}0.5 \% \\
(0.422)\end{array}$ & $\begin{array}{c}0.8 \% \\
(0.297)\end{array}$ & $\begin{array}{c}0.5 \% \\
(0.500)\end{array}$ & $\begin{array}{c}0.4 \% \\
(0.544)\end{array}$ & 44 \\
\hline Difference in mean CAR & $\begin{array}{c}1.5 \% \\
(0.226)\end{array}$ & $\begin{array}{c}5.5 \% \\
(0.008)\end{array}$ & $\begin{array}{c}6.0 \% \\
(0.004)\end{array}$ & $\begin{array}{c}5.8 \% \\
(0.002)\end{array}$ & 75 \\
\hline \multicolumn{6}{|l|}{ Market Model } \\
\hline $\begin{array}{l}\text { Mean CAR for: } \\
\text { Settlements with } \\
\text { reverse payments }\end{array}$ & $\begin{array}{c}2.6 \% \\
(0.029)\end{array}$ & $\begin{array}{c}6.5 \% \\
(0.006)\end{array}$ & $\begin{array}{c}6.4 \% \\
(0.006)\end{array}$ & $\begin{array}{c}6.0 \% \\
(0.003)\end{array}$ & 31 \\
\hline Others & $\begin{array}{c}0.6 \% \\
(0.239)\end{array}$ & $\begin{array}{c}0.9 \% \\
(0.179)\end{array}$ & $\begin{array}{c}0.6 \% \\
(0.372)\end{array}$ & $\begin{array}{c}0.4 \% \\
(0.535)\end{array}$ & 44 \\
\hline Difference in mean CAR & $\begin{array}{c}2.0 \% \\
(0.090)\end{array}$ & $\begin{array}{c}5.6 \% \\
(0.006)\end{array}$ & $\begin{array}{c}5.7 \% \\
(0.005)\end{array}$ & $\begin{array}{c}5.6 \% \\
(0.002)\end{array}$ & 75 \\
\hline \multicolumn{6}{|c|}{ Fama-French 3-Factor Model } \\
\hline $\begin{array}{l}\text { Mean CAR for: } \\
\text { Settlements with } \\
\text { reverse payments }\end{array}$ & $\begin{array}{c}2.7 \% \\
(0.025)\end{array}$ & $\begin{array}{c}6.6 \% \\
(0.005)\end{array}$ & $\begin{array}{c}6.4 \% \\
(0.005)\end{array}$ & $\begin{array}{c}6.0 \% \\
(0.002)\end{array}$ & 31 \\
\hline Others & $\begin{array}{c}0.7 \% \\
(0.211)\end{array}$ & $\begin{array}{c}0.8 \% \\
(0.194)\end{array}$ & $\begin{array}{c}0.7 \% \\
(0.343)\end{array}$ & $\begin{array}{c}0.5 \% \\
(0.428)\end{array}$ & 44 \\
\hline Difference in mean CAR & $\begin{array}{c}2.1 \% \\
(0.078)\end{array}$ & $\begin{array}{c}5.7 \% \\
(0.005)\end{array}$ & $\begin{array}{c}5.7 \% \\
(0.005)\end{array}$ & $\begin{array}{c}5.5 \% \\
(0.002)\end{array}$ & 75 \\
\hline
\end{tabular}

Note: P-values for $\mathrm{H}_{0}(\mathrm{diff}=0)$ in parentheses. 
Table 7. Tests of differences for settlements with and without indication of a reverse payment where the drug represents $5 \%$ or $10 \%$ of the company's revenue, using a $(-3,3)$ event window for all models

\begin{tabular}{|c|c|c|c|c|}
\hline & $\begin{array}{c}\text { Constant } \\
\text { Mean Model }\end{array}$ & $\begin{array}{c}\text { Market } \\
\text { Model }\end{array}$ & $\begin{array}{l}\text { Fama-French } \\
\text { 3-Factor Model }\end{array}$ & $\mathrm{N}$ \\
\hline \multicolumn{5}{|c|}{ Cases where drug is 5\% or more of the company's sales } \\
\hline \multicolumn{5}{|l|}{ Mean CAR for: } \\
\hline $\begin{array}{l}\text { Settlements with } \\
\text { reverse payments }\end{array}$ & $\begin{array}{c}8.7 \% \\
(0.003)\end{array}$ & $\begin{array}{c}8.7 \% \\
(0.002)\end{array}$ & $\begin{array}{c}8.4 \% \\
(0.003)\end{array}$ & 23 \\
\hline Others & $\begin{array}{c}0.2 \% \\
(0.926)\end{array}$ & $\begin{array}{c}1.0 \% \\
(0.655)\end{array}$ & $\begin{array}{c}1.6 \% \\
(0.494)\end{array}$ & 12 \\
\hline Difference in mean CAR & $\begin{array}{c}8.5 \% \\
(0.021)\end{array}$ & $\begin{array}{c}7.8 \% \\
(0.024)\end{array}$ & $\begin{array}{c}6.8 \% \\
(0.052)\end{array}$ & 35 \\
\hline \multicolumn{5}{|c|}{ Cases where drug is $10 \%$ or more of the company's sales } \\
\hline \multicolumn{5}{|c|}{ Mean CAR for: } \\
\hline $\begin{array}{l}\text { Settlements with } \\
\text { reverse payments }\end{array}$ & $\begin{array}{c}9.3 \% \\
(0.004)\end{array}$ & $\begin{array}{c}9.4 \% \\
(0.003)\end{array}$ & $\begin{array}{c}9.2 \% \\
(0.002)\end{array}$ & 21 \\
\hline Others & $\begin{array}{c}1.5 \% \\
(0.724)\end{array}$ & $\begin{array}{c}2.3 \% \\
(0.545)\end{array}$ & $\begin{array}{c}3.0 \% \\
(0.478)\end{array}$ & 7 \\
\hline Difference in mean CAR & $\begin{array}{c}7.8 \% \\
(0.132)\end{array}$ & $\begin{array}{c}7.1 \% \\
(0.139)\end{array}$ & $\begin{array}{c}6.2 \% \\
(0.215)\end{array}$ & 28 \\
\hline
\end{tabular}

Note: P-values for $\mathrm{H}_{0}(\operatorname{diff}=0)$ in parentheses. 
Figure 1. Abnormal Trading Volume with 95\% Confidence Interval
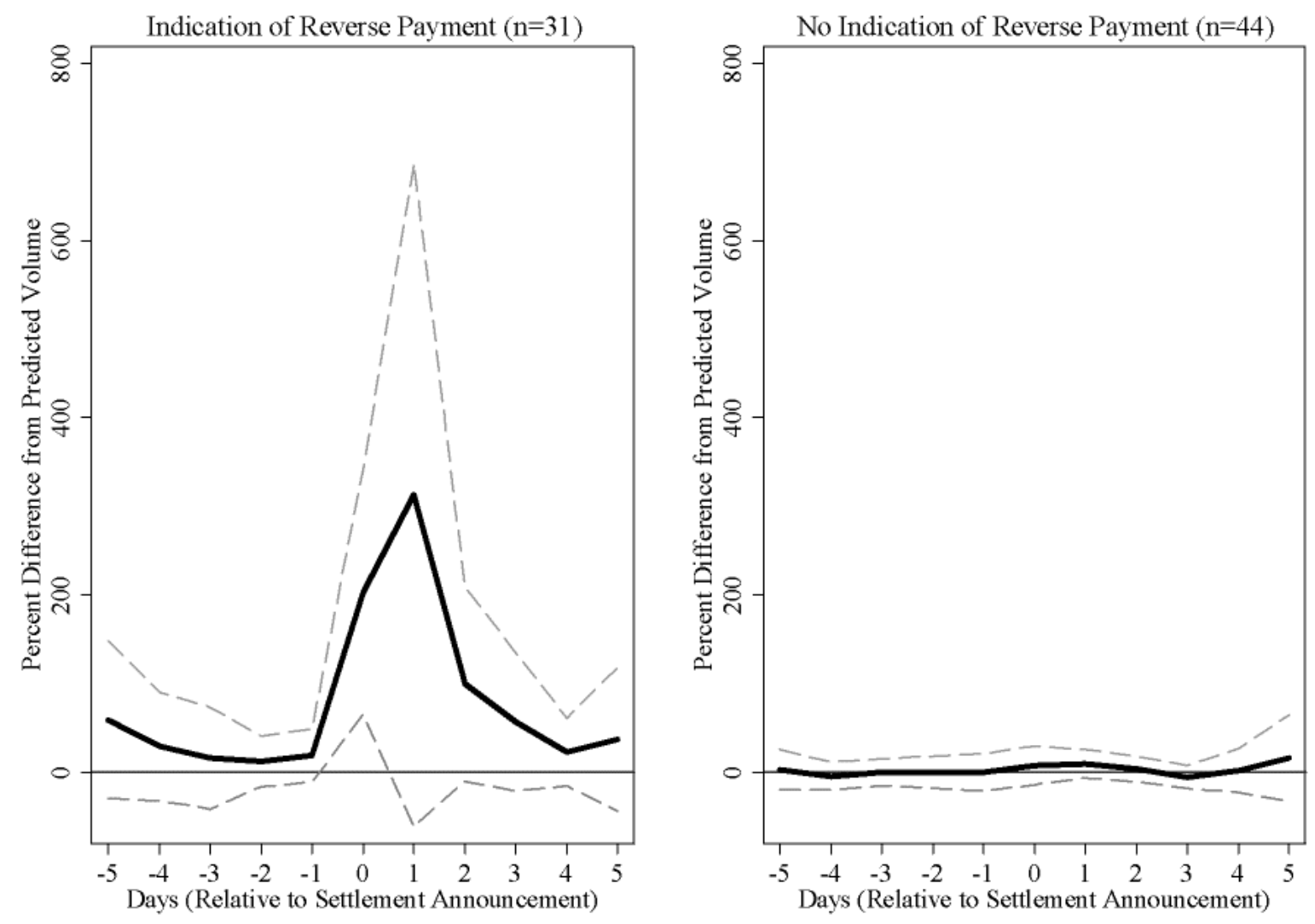

Note: The dashed lines represent the $95 \%$ confidence interval. The variance was computed separately for each trading day from the distribution of settlements on that day. 